\title{
The three-factor model: A study of common features in students' attitudes towards studying and learning science and mathematics in the three countries of the North Calotte region
}

Päivi Tomperi ${ }^{1}$, Inna Ryzhkova², Yulia Shestova², Oleg Lyash², Irina Lazareva², Asya Lyash², Mona Kvivesen ${ }^{3}$, Saeed Manshadi ${ }^{3}$ and Stig Uteng ${ }^{3}$

${ }^{1}$ University of Oulu, Faculty of Education, Finland

2 The Murmansk Arctic State University MASU, Faculty of math and science, Maths, Physics and ICT department, Russia

${ }^{3}$ UiT The Artic University of Norway, Faculty of Humanities, Department of Education, Norway

This study investigated common features of students' attitudes towards studying science and mathematics in comprehensive and secondary schools in three countries. Data were obtained by conducting a survey $(N=581)$ in Norway, Finland and Russia. A Confirmatory factor analysis (CFA) provided a model with a threefactor solution consisting of factors: the perception of the teacher, anxiety towards science and mathematics, and motivation. The results suggest that most students are motivated to study sciences and mathematics. Data analysis indicate gender differences in attitudes to students' future studies and career plans. Most girls recognized the importance of these subjects for their future studies and careers, while boys showed more interest than girls in local career opportunities in industry. Teachers have a significant role in directing students' attitudes toward science and mathematics. Students experienced that the teachers who use innovative teaching approaches, both motivate and reduce anxiety, in their learning process.
Article Details

LUMAT General Issue Vol 8 No 1 (2020), 89-106

Received 5 February 2020 Accepted 14 May 2020 Published 1 June 2020

Pages: 18

References: 33

Correspondence: paivi.h.tomperi@oulu.fi

https://doi.org/10.31129/ LUMAT.8.1.1369

Keywords: attitudes, survey, comparative study, confirmatory factor analysis, secondary school

\section{Introduction}

One of the aspects of globalization is sharp qualitative growth and widespread modern technological solutions that cannot but have a significant impact on the cultural values and lifestyle of people. These trends necessitate the development of technical business awareness and motivation to learn science and mathematics among students. There is a need for educated persons, who have scientific competences being able to function in the modern world to meet challenges requiring the integration of scientific and technical knowledge. 21st-century workforce skills (i.e., adaptability, complex communication/social skills, nonroutine problem solving, self-management/selfdevelopment, and systems thinking) should be provided in science and mathematics classrooms where students can exercise activities, investigations and experiments to 
develop these skills (Binkley et al., 2012; Bybee, 2010). It is well known that while students' interest towards school science and technology is quite high, their interest in science and technology careers and occupations has become alarmingly low in developed countries (for example EC, 2004; Lavonen et al. 2008; Osborne, Simon \& Collins, 2003; Savelsbergh et al., 2016; Schreiner \& Sjøberg, 2010; Wang \& Degol, 2013). This article presents the results of the study conducted by an international research team within the Kolarctic CBC project (KO 2071) "Development of common approaches to involve youth into science and technical sphere - Be Tech!"

Students' attitudes toward science refer specifically to students' emotional conception of science - beliefs, values and feelings - and is a complex, multidimensional construct (Osborne et al., 2003). In their review of the literature, Osborne et al. (2003) identified several constructs that are determinants of students' attitudes influencing science-choice behaviors, including the perception of the science teacher, the nature of the classroom environment, achievement in science, the value of science, motivation, attitudes of peers and friends towards science, attitudes of parents towards science, enjoyment of science, anxiety towards science, self-esteem at science, and fear of failure on course. The last three components are included in the concept of self-efficacy, which is an expectancy about one's capabilities to learn or perform a given task (Bandura, 1977). Efficacy beliefs are essential for the motivational process since individuals are unlikely to engage in behaviors and activities at which they do not expect to succeed. Sense of self-efficacy has been linked to the adoption of challenging goals, effort investment, persistence and resiliency in the face of difficulty (Bandura, 1997).

According to Walker, Smith and Hamidova (2013) the multi-dimensional structure of attitudes views attitudes as consisting of three distinct domains: affect, behavior, and cognition. Enjoyment for learning science can lead to positive feelings towards science-related activities at school (affective component). Students' positive attitudes towards science are visible when they are reading science magazines for pleasure and visit science exhibitions (behavioral component). Expose to evidence for global warming may influence students' beliefs about the importance of science (the cognitive component). Fishbein and Ajzen (1975) divide attitudes to the affective domain and beliefs to the cognitive domain. They made a notion that beliefs can change as a result of one's attitudes and behavior, and an attitude may influence the formation of new beliefs. If a student performs successfully on a science test, he or she may form a new belief that science is not that difficult after all. A student's attitudes towards studying science and mathematics is a function of his or her beliefs about the 
attributes relating to studying science and math, and an evaluation of those attributes. Beliefs and attitudes are interrelated so that beliefs are primary and attitudes secondary. It follows that student's beliefs about studying and learning science contribute to the formation of his or her attitudes towards studying and learning science (Fishbein et al., 1975; Walker et al., 2013).

Teacher and the learning environment are considered the main factors in defining the students' attitudes towards science and mathematics. Savelsbergh et al. (2016) reviewed 56 publications to study the effects of different innovative teaching approaches on student's attitudes and achievement. Innovative teaching approaches included context-based, inquiry-based, ICT-enriched, collaborative and extracurricular. They found significant positive effects of innovative teaching approaches on both attitude and achievement. However, they could not find different effects on different kinds of teaching approaches and concluded that rather than a type of teaching approach, it is the quality of content and the implementation that matters.

Many students perceive science as difficult. Lavonen et al. (2008) found a strong correlation between perceived difficulty (feeling lack of competence) of a subject and the uninterestingness of the subject. In science, the ideas and concepts exist at three different thought levels: macro, micro and symbolic levels (Johnstone, 1991). Students may work with all three levels of the same concept during one lesson and according to Johnston, the interaction of these three levels may cause overloading of the working memory capacity hence causing difficulty in conceptualizing various areas in science. When students use scientific terms and symbols new to them, it may cause difficulty in their conceptualizing process. This is because of the weak connection between their cognitive structures and scientific concepts/symbols, causing overloading of the working memory (Bahar \& Polat, 2007). Students often have misconceptions about science phenomena that do not correspond well with the scientific knowledge to be taught. These alternative conceptions are enduring and resistant to change by conventional teaching strategies (Driver, 1981). To be able to cover the science topics given in the curriculum, teachers may adopt teacher-centered teaching approaches as the student-centered teaching approaches are more timeconsuming (Bahar et al., 2007).

Positive experiences in school science, including a supportive relationship with teachers and pedagogy, which emphasize the relevance of science, contribute to interest and enjoyment of science. However, these factors and positive parental attitudes to science don't translate into aspirations in science. Aspirations may be nurtured and developed to the point in which students can imagine themselves in 
some science-related roles and can perceive science careers as possible and achievable. Children whose families have high levels of science capital, for example, parents with science degrees and/or who work in science jobs, are more likely to express science aspirations (DeWitt \& Archer, 2015). Recent research in England (Sheldrake, Mujtaba \& Reiss, 2017) has measured students' perceived utility in science (valuing science through thinking that science leads to various benefits such as increased skills and facilitating careers) which associated strongly with sciencerelated career aspirations. They concluded that in science education, highlighting the applications and relevance of science to everyday life would be beneficial.

There is an apparent gender difference in attitudes towards science. Gender is not the result of a person's sex but produced through continuous verbal and bodily performances in which a person "do girl" or "do boy" (Butler, 1990). Many girls consider that gender is not a barrier to make study and career choices, yet their actual choices remain traditional. The common association of science with cleverness means that science aspirations are not experienced appropriate for everyone (Archer et al., 2013). The gender difference is the largest in the developed countries. In wealthy countries, few students want to become scientists, and especially girls state that they don't want to work in technology. Girls want to work with people and help other people, whereas boys are less interested in such work. Researchers conclude that to obtain a better gender balance in the future, and the science curricula must become more value-, people-, and environment-oriented (Schreiner et al., Sjøberg, 2010).

Countries with high levels of gender equality, for instance, in Norway and Finland, the gender gap in tertiary level student enrollment in STEM studies and college graduation rates in STEM fields is the largest (World Economic Forum, 2015). Researchers explain that economic and life quality risks are lower in gender-equal countries compared to less gender-equal countries where STEM fields often represent higher salary occupations and stability (Stoet \& Geary, 2018).

In their research, Wang, Eccles, and Kenny (2013) noted that people with high mathematical and high verbal abilities could find a wider choice of careers in both STEM and non-STEM fields than those with high mathematical and moderate verbal abilities. The group with high mathematical and high verbal abilities included more girls than boys. In recent research (Stoet et al., 2018), most boys scored relatively higher in science than their all-subject average, and most girls scored relatively higher in reading than their all-subject average. Pupils are usually recommended in secondary education to make choices in their coursework based on their academic strengths and enjoyment. When girls have even abilities in science or mathematics 
with boys, science, or mathematics is more likely a personal academic strength for boys than girls (Stoet et al., 2018).

\subsection{Purpose of the study}

In this study, the goal was to find common features in secondary school students' attitudes towards studying and learning science and mathematics, and the factors which have an influence on them, in Finnish, Norwegian, and Russian North Calotte region by using combined data obtained through the same survey. The research questions are:

1. What are the common features in attitudes towards studying and learning science and mathematics among secondary school students?

2. Which factors influence secondary school students' attitudes towards studying and learning science and mathematics?

3. Are there gender differences in attitudes among secondary school students towards studying and learning science?

\section{Methodology}

\subsection{Survey}

The BeTech! Instrument was designed as a starting point of the international project and aimed at revealing the existing attitudes towards learning and studying science and mathematics in the participating schools according to project goals. There are cultural differences and similarities in students' interests, priorities, experiences, career aspirations, etc. which are relevant for teaching and learning of science and mathematics. The BeTech! Instrument is based-on common views, perspectives and value positions. There is a specific theoretical framework and precisely defined research questions. According to Fishbein and Ajzen (1975), attitudes are affective variables, so the questionnaire is aimed at assessing students' feelings instead of what they assume to be true about science (i.e., beliefs). The items were created to explore students' attitudes in the context of school science, not the nature and value of science in general (Osborne et al., 2003; Walker et al., 2013). Specific questions, for which we looked for answers through questionnaire separately in three participating countries, and the items with which we aimed at obtaining the answers, were: 
1. What are the students' attitudes towards studying science and math? (Items 1, $2,4-6,36)$

2. What role do science and math play in the students' future (study and work) plans? (Items 3, 7-9)

3. What is the influence of attitudes of parents, peers, and friends to students' attitudes towards studying science and math? (Items 10-17)

4. What is the influence of teaching to attitudes towards studying science and math? (Items 19-35)

5. What is the influence of local industry and work opportunities to students' attitudes towards studying science and math? (Items 8 and 18)

The BeTech! Instrument is a questionnaire consisting mainly of closed, prestructured questions, and the respondents give their answers by choosing the alternative appropriate to their view. The questionnaire was created using Webropol 3.o survey and reporting tool and students answered it online anonymously. Closed questions were chosen because then the data is rapidly collected and coded, and easy to compare. Because they do not require any extended writing, they are easily and quickly answered. In addition to multiple-choice questions concerning gender, favorite school subjects, and estimations of one's own skills in science and mathematics, the questionnaire contained 36 items (see Appendix) on a 5-point Likert-scale ranging from $1=$ strongly agree through $3=$ not sure to $5=$ strongly disagree. Items deal with each of the nine components which are known to contribute an individuals' attitudes towards science: the perception of the science teacher (items 22, 23, 27-29, 32), the nature of the classroom environment (items 19-22, 24, 28-36), achievement in science (items 4-6, 25, 26, 36), the value of science (items 3, 7-9, 18), motivation towards science (items 1, 2, 4-9, 16-18, 36), attitudes of peers and friends towards science (items 10, 11, 13, 15, 17), attitudes of parents towards science (items $12,14,16,17$ ), enjoyment of science (items 1, 2, 4, 8, 10, 11, 17, 36), and self-efficacy (items 4-6, 21, 24-26, 36) (e.g., Osborne et al., 2003).

We chose a simple Likert scale because it has advantages when the instrument is used in different cultures and translated into other languages. The risks of the middle category, "not sure," was recognized and discussed. The BeTech! Instrument was developed in English and translated into Finnish, Norwegian, and Russian. Each item is simple and rather short so that possible translation errors could be reduced to a minimum. Research partners come from a variety of backgrounds and they carry with them their own perspectives, theoretical approaches, and research interests, which was also a challenge in the development of the questionnaire, but it also enables 
partners to learn from each other. To ensure that the questionnaire would address the issues that it was intended to do, the instrument was developed through a process of discussion, reflection, trying out, improving, and trying out again because it was the starting point of the BeTech! The project and the time to develop it was short. The questionnaire is a product of international collaboration, but in the end, it was the Finnish partner that took the final decision.

The questionnaire was translated into Finnish and piloted in a Finnish classroom consisting of 16 eight graders. Through it we obtained experience on procedural matters and practicalities on organizing the survey. The researcher was face-to-face with respondents and got spontaneous reactions from the students and their teacher to the items. Based on their feedback, the questionnaire was revised.

\subsection{Participants}

580 students in total, aged 12-16, answered the questionnaire. The age distribution of respondents was: 42\% 13-years, 10\% 14-years, 40\% 15-years, and 8\% 16-years.

In Murmansk and the Murmansk region, Russia, four comprehensive schools participate in the project and 268 students (118 girls and 144 boys) answered the questionnaire. Natural sciences are composed of physics, chemistry, biology, and geography. Besides, the questionnaire studied interest in mathematics and ICT. All these subjects are compulsory in Russian schools: mathematics is studied throughout the whole school period from grade one to eleven; biology and geography start in grade five; physics starts in grade seven, chemistry and ICT start in grade eight (in some schools ICT can be taught earlier as an optional subject). In grades five to eleven, natural sciences are studied as separate subjects by subject teachers. Subject teachers are usually specialized in one or two subjects.

In Oulu, Finland, two comprehensive schools participate in the project, and 175 students (105 girls and 70 boys) answered the questionnaire. Natural sciences are composed of physics, chemistry, biology, and geography. ICT is not compulsory. In grades seven to nine, natural sciences are taught as separate subjects by subject teachers. Subject teachers are usually specialized in two or three subjects such as mathematics, physics, and chemistry, or biology, and geography. Mathematics is studied throughout the whole school period in grades one to nine.

In Alta, Norway, two schools participate in the project, one comprehensive school and one secondary school. 138 students (63 girls and 75 boys) answered the questionnaire. Natural sciences are composed of physics, biology, chemistry and geology, and are studied as one subject in grades one to ten. Mathematics is studied 
throughout the whole school period in grades one to ten. In Norway, ICT is not an own subject but compulsory in all subjects.

\subsection{Confirmatory factor analysis (CFA)}

To examine the underlying factor structure of the questionnaire, a series of exploratory latent structure analyses (EFA) were conducted. We applied mainly the fa-function from the psych-package written for R (R Core Team, 2019) and SPSS (IBM, 2017) statistic program package to get the factors with corresponding items. Both packages gave similar results. Retained factors were rotated using oblique (oblimin) rotation (Hendrickson \& White, 1964). These factors were then used as a base for a confirmatory factor analysis (CFA), where the resulting model is depicted (see Figure 1). The lavaan (Revelle, 2015) and SemPlot (Epskamp, 2015) packages for $\mathrm{R}$ was used here. The fit of the model to the data was evaluated using standard fit indices (chi-square, comparative fit index (CFI), root mean square error of approximation (RMSEA), and standardized root mean square residual (SRMR)). The non-significant chi-square test statistic, CFI of .90 or greater, RMSEA of .o8 or lower, and SRMR of .08 or lower each reflect an adequate model fit (Kline, 2015). In our model, the chi-square statistic was significant with a value of 330.5. However, this statistic tends to be significant with larger samples, here respondents (Mair, 2018). Thus, it is not that important in this study. Further, the CFI was 0.958, the RMSEA was 0.075, and the SRMR was 0.069. Thus, it is an adequate fit.

Three factors extracted from attitude items with factor loadings and rounded percentages of students' responses to the questionnaire are shown in Table 2. Additionally, a T-test was conducted to compare differences between boys and girls. We chose the independent T-test, which was done by the GNU PSPP-package. 


\section{Results and discussion}

The results are presented in two parts. The results from the survey with examples and gender differences are presented first. Secondly, we report the results of the CFAstudy, the obtained three-factor model.

\subsection{Survey}

With six items, we investigated students' attitudes towards studying science and math (see Table 1). More than half of the respondents indicated that they enjoyed studying science. At the same time, about one-fourth of respondents in Finland and Russia feared that they might fail in their studies, while in Norway, respondents' fear of failure was distinctly lower. As the results show, among respondents, girls in Finland and Russia felt a little bit more insecure in their development in science and mathematics, but in Norway, more boys than girls experienced a fear of failure.

When asked what role science and math played in the students' future study and work plans, over half of the respondents recognized the importance and necessity of studying natural sciences and mathematics for the successful development of other school subjects (item 7). More girls than boys agreed in this matter in each country, and there is a significant gender difference. Also, the importance of studying natural sciences and mathematics for admission to the desired upper secondary school was expressed (item 9). This allows us to conclude that students are motivated to study natural sciences and mathematics, but this extrinsic motivation is mainly related to continuing education at the upper secondary level. 
Table 1. Item examples with gender differences in attitudes. Rounded percentages of students' responses in the two positive extremes of "strongly agree" and "agree."

\begin{tabular}{lllll}
\hline Items & NOR & RUS & FIN & SD \\
& $\%$ & $\%$ & $\%$ & \\
\hline
\end{tabular}

What are the students' attitudes towards studying science and math? Items 1, 2, 4-6, 36
1. I enjoy learning science.
Boys 70
$61 \quad 53$
1,044
Girls 41
5948
4. Studying science and math is risky: I can fail.

Boys $\quad 13 \quad 22 \quad 24$
1,108

$\begin{array}{llll}\text { Girls } & 8 & 29 & 26\end{array}$

What role do science and math play in the students' future (study and work) plans? Items 3, 7-9

$\begin{array}{lllllll}\text { 7. I need math to learn other school subjects. } & \text { Boys } & 53 & 60 & 61 & 1,066^{*} \\ & \text { Girls } & 54 & 65 & 74 & \\ \text { 9. I need to do well in science and math to get into the } & \text { Boys } & 47 & 60 & 47 & 1,193 \\ \text { upper secondary school I want. } & \text { Girls } & 35 & 65 & 55 & \end{array}$

What is the influence of attitudes of parents, peers, and friends on pupils' attitudes towards studying science and math? Items 10-17

16. My parents are proud of my achievements in science and math.

$\begin{array}{lllll}\text { Boys } & 60 & 56 & 64 & 1,115 \\ \text { Girls } & 52 & 60 & 70 & \\ \text { Boys } & 9 & 35 & 11 & 1,317 \\ \text { Girls } & 8 & 33 & 32 & \end{array}$
math.

What is the influence of teaching to attitudes towards studying science and math? Items 19-35

$\begin{array}{llllll}\text { 21. I always know clearly the goal of learning in math. } & \text { Boys } & 60 & 60 & 64 & 1,139^{* *} \\ & \text { Girls } & 44 & 47 & 61 & \\ \text { 22. Teacher listens to our experiences and opinions and } & \text { Boys } & 64 & 44 & 47 & 1,174^{*} \\ \text { takes them into account in teaching } & \text { Girls } & 52 & 33 & 52 & \\ \text { 23. Teacher is enthusiastic about the subject she/he is } & \text { Boys } & 64 & 57 & 51 & 1,070^{*} \\ \text { teaching. } & \text { Girls } & 54 & 53 & 69 & \\ \text { 31. We memorize science facts and principles in every } & \text { Boys } & 43 & 55 & 53 & 0,958^{*} \\ \text { lesson. } & \text { Girls } & 38 & 40 & 60 & \end{array}$

What is the influence of local industry and work opportunities to students' attitudes towards studying science and math? Items 8 and 18

$\begin{array}{llllll}\text { 18. I would like to work in local industry or company in } & \text { Boys } & 27 & 14 & 24 & 1,254 \\ \text { the future. } & \text { Girls } & 10 & 6 & 8 & \\ \text { 8. I would like a job where I use science and math. } & \text { Boys } & 17 & 45 & 19 & 1,220 \\ & \text { Girls } & 18 & 34 & 17 & \end{array}$

${ }^{*} \mathrm{p}<0,05 ; * \mathrm{p}<0,0001$ in T-testing

It is well known that the attitudes of parents, peers, and friends have an influence on students' attitudes towards studying and learning science and math. More than half of the respondents experienced that their success in studying mathematics and science is important for their parents (item 16); In Finland and Russia, more girls than 
boys agreed with this statement, while in Norway, more boys than girls agreed. The influence of the friends on the attitudes (item 15) dispersed considerably in three countries. Among respondents, one-third of Russian pupils and Finnish girls had friends who encouraged them to study science and math, while only one-tenth of Norwegian pupils and Finnish boys had such friends.

The influence of teaching on attitudes towards studying and learning science and mathematics is crucial according to research. Among our respondents, teaching brought up the most significant gender differences in attitudes (items 21-23, 31). In all three countries, there are both teacher-centered and student-centered approaches used, excursions and fieldwork were not widely used, and the computers were not used in improving learning, like processing and analyzing data. Student-centered approaches (e.g., item 22) seem to be more widely used in Norway than teachercentered (e.g., item 31) compared to Finland and Russia. In general, the majority of students noted the enthusiastic attitude of teachers to the taught subject (item 23).

When asked about the influence of local industry and work opportunities on students' attitudes towards studying science and math (item 18), the responses to this issue showed that despite a fairly high motivation for studying natural sciences and mathematics, as well as experienced support from parents and friends, a very small number of students wanted and exhibited a readiness to work at local industry enterprises. It can be seen from the above data (see Table 1) that the traditional gender bias exists here: boys are more interested than girls in the practical use of knowledge gained in the field of science and mathematics.

\subsection{Confirmatory factor analysis}

The model (see Figure 1) consists of three factors: The perception of the (science/mathematics) teacher (FA1), anxiety towards science and mathematics (FA2), and motivation (FA3) (see Table 2). The factors are named after components, of which the attitude construct is known to comprise (Osborne et al., 2003). The perception of the teacher correlates positively with the motivation to learn and study science and mathematics, and negatively with the anxiety towards science and mathematics (covariances 0,262, -0,167, and -0,247, respectively). Teachers have a significant role in directing students' attitudes positively towards learning and studying science and mathematics. Based-on students' responses to the questionnaire, we found out that there are both teacher-centered and studentcentered approaches used in teaching, but this model (Items 22 and 32) portrays especially teachers who hold a constructivist view of learning. They are aware of ideas 
that students bring to the learning occasion and provide them with opportunities to utilize their ideas in different contexts. The classroom atmosphere encourages students to express and discuss ideas. According to research, constructivist teaching approaches like inquiry-based and collaborative learning have positive-

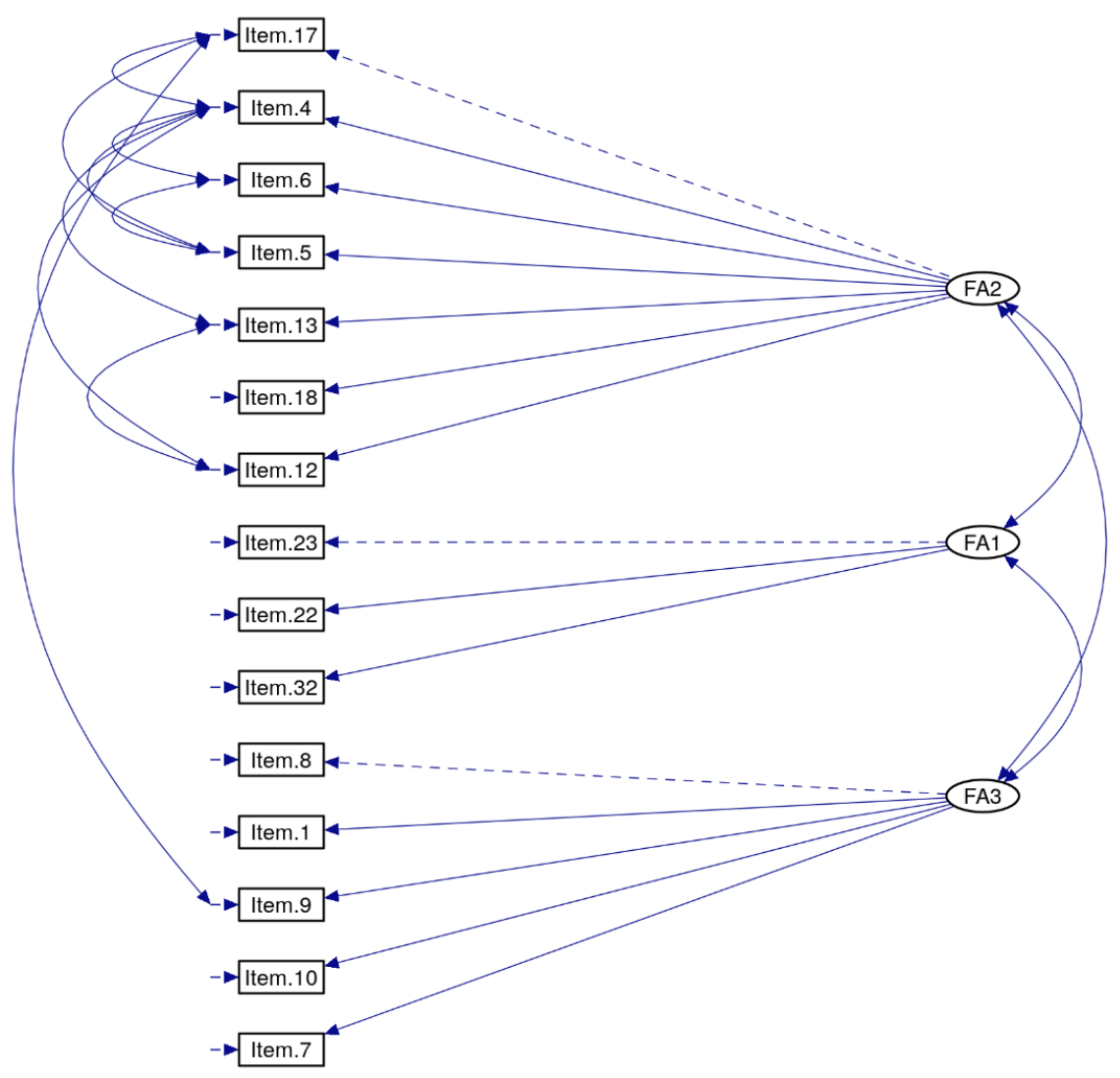

Figure 1. Three-factor model (CFA) of pupils' attitudes towards learning and studying science and mathematics.

effects on attitudes and achievement (Savelsbergh et al., 2016). Science teachers work to understand students' thinking, challenge misconceptions, and help students to make links to science concepts that lead to a meaningful and comprehensive scientific understanding. Teachers need to find a balance of teacher-centered and studentcentered activities when deciding how much explicit instruction to provide and to what extent students can assume responsibility for their own learning. When science is taught as inquiry, it presents challenges to students, as it requires critical attitude, scientific skepticism, tolerance for ambiguity, and patience. These challenges are greater for students whose homes do not encourage inquiry practices but appreciate conventional teaching methods (Lee \& Luykx, 2007). 
Table 2. Overview of the factors.

\begin{tabular}{|c|c|c|c|}
\hline Description & Loading & $\begin{array}{l}\text { Agree } \\
\%\end{array}$ & $\begin{array}{l}\text { Disagree } \\
\%\end{array}$ \\
\hline \multicolumn{4}{|l|}{ FA1: The perception of the teacher } \\
\hline 23. Teacher is enthusiastic about the subject she/he is teaching. & 1.00 & 59 & 12 \\
\hline $\begin{array}{l}\text { 22. Teacher listens to our experiences and opinions and takes them } \\
\text { into account in teaching. }\end{array}$ & 1.282 & 46 & 23 \\
\hline $\begin{array}{l}\text { 32. Teacher encourages us to decide our own problem-solving } \\
\text { procedures in math. }\end{array}$ & 0.891 & 42 & 19 \\
\hline \multicolumn{4}{|l|}{ FA2: Anxiety towards science and mathematics } \\
\hline $\begin{array}{l}\text { 17. Negative attitudes of the people in my close circle towards } \\
\text { science and math negatively affects my eagerness. }\end{array}$ & 1.00 & 29 & 51 \\
\hline 4. Studying science and math is risky: I can fail. & -0.285 & 32 & 37 \\
\hline 6. Biology is more difficult for me than for many of my classmates. & 0.678 & 20 & 52 \\
\hline 5. Physics is more difficult for me than for many of my classmates. & 0.224 & 28 & 41 \\
\hline 13. My siblings often help me with my science and math homework. & -0.946 & 21 & 66 \\
\hline 18. I would like to work in local industry or company in the future. & -1.082 & 27 & 41 \\
\hline $\begin{array}{l}\text { 12. My parents often help me with my science and math homework. } \\
\text { FA3: Motivation }\end{array}$ & -0.679 & 33 & 50 \\
\hline 8. I would like a job where I use science and math. & 1.00 & 39 & 32 \\
\hline 1. I enjoy learning science. & 0.888 & 63 & 12 \\
\hline $\begin{array}{l}\text { 9. I need to do well in science and math to get into the upper } \\
\text { secondary school I want. }\end{array}$ & 0.651 & 60 & 17 \\
\hline 10. Most of my friends like studying science & 0.676 & 32 & 27 \\
\hline 7. I need math to learn other school subjects. & 0.810 & 67 & 13 \\
\hline
\end{tabular}

The second-factor, "Anxiety towards science and mathematics," correlates negatively with the other two factors. It is mainly caused by negative attitudes of the people in students' close circle (Item 17). Fortunately, half of the students disagree with the statement. All students experience anxiety sometimes. State anxiety is defined as unpleasant emotional arousal in response to situations that are perceived as threatening (Spielberger, 1983). Fear of failure (Item 4) is experienced by one-third of students, but it loads negatively on this factor. However, items 17 and 4 have a positive correlation. Self-determination is the ability to have choices and some degree of control in what we do and how we do it (Deci, Vallerand, Pelletier, \& Ryan, 1991). To promote self-determination in students, science teachers should give students opportunities to organize their own experiments instead of requiring them to follow rote directions. At worst, when students lack self-determination, they can develop learned helplessness believing they will fail no matter what they do, so they don't practice or improve their science and mathematics skills and abilities. Self-regulated learners select more challenging tasks, make more effort on assignments, and if they fail, they attribute their failure to controllable, internal causes such as a lack of preparation. 
Anxiety can also be caused by a lack of competence. Self-efficacy is domainspecific, for example, a student can have high self-efficacy with respect to knowledge and skills in biology (Item 6) but low self-efficacy with respect to knowledge and skills in physics (Item 5). It is known that students' self-efficacy predicts their performance in science and mathematics. It derives from mastery experiences, vicarious experiences, and social persuasion (Bandura, 1997). Mastery experiences are students' actual experiences of which success increases self-efficacy, and failure decreases it. Vicarious experiences connect with the observation of others (role models) such as teachers, parents, siblings, peers, or celebrities. The more students identify with their role models, the stronger the influence is on them. Social persuasion can also influence students and make them try harder in science and math. Help available with science and math homework by siblings and parents (Items 12 and 13) possibly reduces the anxiety due to negative loadings on this factor.

Motivation is an internal state that arouses, directs, and sustains students' behavior (Koballa, Jr. \& Glynn, 2007). Attitudes influence motivation, which in turn influences learning and ultimately behavior. Motivation explains why students pursue certain goals when learning science, how intensively and how long they pursue, and what feelings and emotions characterize them in that process. Motivation to perform an activity for its own sake is intrinsic, whereas learning to earn grades or avoid detention represents extrinsic motivation. Students are often motivated to perform tasks for both intrinsic and extrinsic reasons. The extent to which students are intrinsically motivated depends on how self-determined they are, their goal-oriented behavior, their self-regulation, their self-efficacy, and the expectations that teachers have of them. Intrinsically motivated activities promote feelings of competence and independence (Koballa, Jr. \& Glynn, 2007). A student who is interested or curious about a science topic has a readiness to pursue it and enjoys the learning process (Item 1) but may also be motivated by the prospect of good grade which may secure entry into the upper secondary school one intends (Item 9) or support career aspirations (Item 8). Student's motivation to achieve at a high level in mathematics is more likely if he/she recognizes that struggling with it benefits him/her when studying and learning other school subjects, too (Item 7). On the other hand, there is a correlation between items 17 and 9 (see Figure 1) showing the existence of the contradictory atmosphere, which can influence students. Negative attitudes of the people in a close circle towards science and math affects student's eagerness to study those subjects, and at the same time, in order to get admission to the desired upper secondary school, he/she should succeed in them. 
In general, the model implies that students who answered the questionnaire in the three countries of the North Calotte region experienced that enthusiastic teachers using innovative teaching approaches both motivate and reduce anxiety in their learning process. This result encourages us to proceed in our project to find those best practices that support student-centered approaches in science and mathematics teaching and learning.

\section{Conclusions and implications}

Despite the differences and national characteristics in studying sciences and mathematics at schools in Norway, Finland and Russia (in which grade subjects are studied, how long studies last, etc.), most respondents liked studying sciences. Students recognized the importance of mathematics for studying other school subjects and for future education at the upper secondary level. Unfortunately, the career aspirations in the fields of science and mathematics were modest, especially among respondents from Finland and Norway.

Based on the research results, the factors influencing secondary school students' attitudes towards studying and learning science and mathematics, are attitudes of parents and friends, and the teaching. In teaching, both teacher-centered and student-centered approaches were used, but according to the three-factor model, a student-centered approach is directly linked to motivation and indirectly to anxiety. In all three countries, field trips or fieldwork were seldom used. Surprisingly, computers were rarely used in promoting learning.

Responses to the questionnaire revealed gender differences in attitudes to implemented teaching approaches at schools and to future study and work plans. In all three countries, more girls than boys had realized the importance of studying science and mathematics for their prospects in the future. On the other hand, boys were more interested in local career opportunities in the industry than girls.

Affective elements in learning have become an important topic in science education research. Science learning experiences that are fun and personally fulfilling are likely to foster positive attitudes towards science learning and lead to improved achievement. Professional learning opportunities should be provided for teachers that will help prepare them to encourage unmotivated science students. In the North Calotte region, for example, career guidance excursions to local enterprises and out of school learning opportunities, as well as the use of computers in learning, would help students to understand the crucial role of natural sciences and mathematics in the future professions. 


\section{Acknowledgements}

We express our gratitude to schools and teachers collaborating with us. The project is funded by the Kolarctic CBC, EU, Russia, Norway and Finland. This article has been produced with the assistance of the European Union. The contents of this article are the sole responsibility of the writers and can in no way be taken to reflect the views of the European Union.

\section{References}

Archer, L., DeWitt, J., Osborne, J., Dillon, J., Willis, B., and Wong, B. (2013). 'Not girly, not sexy, not glamorous': primary schoolgirls' and parents' constructions of science aspirations. Pedagogy, Culture \& Society, 21(1), 171-194. https://doi.org/10.1080/14681366.2012.748676

Bahar, M., and Polat, M. (2007). The science topics perceived difficult by pupils at primary 6-8 classes: Diagnosing the problems and remedy suggestions. Educational Sciences: Theory and Practice, $7(3), 1113-1130$.

Bandura, A. (1977). Self-efficacy: Toward a unifying theory of behavioral change. Psychological Review, 84, 191-215. https://doi.org/10.1037/0033-295X.84.2.191

Bandura, A. (1997). Self-efficacy: The exercise of control. New York: Freeman.

Binkley, M., Erstad, O., Herman, J., Raizen, S., Ripley, M., Miller-Ricci, M., and Rumble, M. (2012). Defining 21 st-century skills. In P. Griffin, B. McGaw \& E. Care (Eds.), Assessment and Teaching of $21^{\text {st }}$ century skills, pp.17-66. Dordrect: Springer.

Butler, J. (1990). Gender trouble: Feminism and the subversion of identity. London: Routledge.

Bybee, R. (2010). The teaching of science: $21^{\text {st }}$-century perspectives, p.133. Arlington, VA: National Science Teacher Association (NSTA) Press.

Deci, E.L., Vallerand, R.J., Pelletier, L.G., Ryan, R.M. (1991). Motivation and education: The selfdetermining perspective. Educational Psychologist, 26, 325-346.

https://doi.org/10.1080/00461520.1991.9653137

DeWitt, J., and Archer, L. (2015). Who aspires to a science career? A comparison of survey responses from primary and secondary school students. International Journal of Science Education, 37(13), 2170-2192. https://doi.org/10.1080/09500693.2015.1071899

Driver, R. (1981). Pupils' alternative frameworks in science. European Journal of Science Education, 3(1), 93-101. https://doi.org/10.1080/0140528810030109

Epskamp, S. (2015). semPlot: Unified Visualizations of Structural Equation Models. Structural Equation Modeling. doi:10.1080/10705511.2014.937847

European Commission (2004). Europe needs more scientists!

Fishbein, M., and Ajzen, I. (1975). Belief, attitude, intention, and behavior: An introduction to theory and research, Reading, MA: Addison-Wesley.

Hendrickson, A. E., \& White, P. O. (1964). Promax: A quick method for rotation to oblique simple structure. British Journal of Statistical Psychology. https://doi.org/10.1111/j.20448317.1964.tb00244.x

Johnstone, A. (1991). Why science is difficult to learn? Things are seldom what they seem? Journal of Computer Assisted Learning, 7, 75-83. https://doi.org/10.1111/j.1365-2729.1991.tb00230.x

Kline, R. B. (2015). Principles and practices of structural equation modelling Ed. 4. Methodology in the social sciences. New York: The Guilford Press 
Koballa, Jr., T.R., \& Glynn, S.M. (2007). Attitudinal and motivational constructs in science learning, in S.K. Abell \& N.G. Lederman (Eds.) Handbook of Research on Science Education, pp. 75-102, Mahwah, NJ: Lawrence Erlbaum Associates, Inc.

Lavonen, J., Gedrovics, J., Byman, R., Meisalo, V., Juuti, K., and Uitto, A. (2008). Students' motivational orientations and career choice in science and technology: A comparative investigation in Finland and Latvia, Journal of Baltic Science Education, 7(2), 86-102.

Lee, O., \& Luykx, A. (2007). Science education and student diversity: Race/Ethnicity, language, culture, and socioeconomic status, in S.K. Abell \& N.G. Lederman (Eds.) Handbook of Research on Science Education, pp. 171-198, Mahwah, NJ: Lawrence Erlbaum Associates, Inc.

Mair, P. (2018). Modern Psychometrics with R. Springer.

Osborne, J., Simon, J., \& Collins, S. (2003). Attitudes towards science: A review of the literature and its implications. International Journal of Science Education, 25(9), 1049-1079. https://doi.org/10.1080/0950069032000032199

Revelle, W. (2015). Package 'psych' - Procedures for Psychological, Psychometric and Personality Research. $R$ Package.

$\mathrm{R}$ core Team, (2019). $R$ : A language and environment for statistical computing

Savelsbergh, E. R., Prins, G. T., Rietbergen, C., Fechner, S., Vaessen, B. E., Draijer, J. M., \& Bakker, A. (2016). Effects of innovative science and mathematics teaching on student attitudes and achievement. Educational Research Review, 19, 158-172. https://doi.org/10.1016/j.edurev.2016.07.003

Sheldrake, R., Mujtaba, T., and Reiss, M. J. (2017). Science teaching and students' attitudes and aspirations: The importance of conveying the applications and relevance of science. International Journal of Educational Research, 85, 167-183. https://doi.org/10.1016/j.ijer.2017.08.002

Schreiner, C., and Sjøberg, S. (2010). The Rose Project. An overview and key findings. University of Oslo.

https://roseproject.no/network/countries/norway/eng/nor-Sjoberg-Schreiner-overview-2010.pdf

Spielberger, C.D. (1983). Manual for the state-trait anxiety inventory (STAI). Palo Alto, CA: Consulting Psychologists Press.

Stoet, G., and Geary, D.C. (2018). The gender-equality paradox in science, technology, engineering, and mathematics education, Psychological Science, 29(4), 581-593. https://doi.org/10.1177/0956797617741719

Walker, D.A., Smith, M.C., and Hamidova, N.I. (2013). A structural analysis of the attitudes toward science scale: Students' attitudes and beliefs about science as a multi-dimensional composition. Multiple Linear Regression Viewpoints, 39(2), 38-48.

Wang, M-T., Eccles, J., and Kenny, S. (2018). Not lack of ability but more choice: Indvidual and gender differences in choice of careers in science, technology, engineering, and mathematics. Psychological Science, 24(5), 770-775. https://doi.org/10.1177/0956797612458937

Wang, M-T., and Degol, J. (2013). Motivational pathways to STEM career choices: Using expectancy value to understand individual and gender differences in STEM fields.

Developmental Review, 33, 304-340. https://doi.org/10.1016/j.dr.2013.08.001

World Economic Forum (2015). The Global Gender Gap Report 2015. Geneva, Switzerland: World Economic Forum. http://reports.weforum.org/global-gender-gap-report-2015/

IBM Corp. Released 2017. IBM SPSS Statistics for Windows, Version 25.0. Armonk, NY: IBM Corp. 


\section{Appendix}

Items in the questionnaire

\section{No. Item}

1 I enjoy learning science.

2 Math is boring.

3 I think that the natural work scientists do is important.

4 Studying science and math is risky: I can fail.

5 Physics is more difficult for me than for many of my classmates.

6 Biology is more difficult for me than for many of my classmates.

7 I need math to learn about other school subjects.

8 I would like a job where I use science and math.

9 I need to do well in science and math to get into the upper secondary school I want.

10 Most of my friends like studying science.

11 Most of my friends like studying math.

12 My parents often help me with my science and math homework.

13 My siblings often help me with my science and math homework.

14 My parents encourage me to study science and math.

15 My friends encourage me to study science and math.

16 My parents are proud of my achievements in science and math.

17 Negative attitudes of the people in my close circle towards science and math negatively affect my eagerness.

18 I would like to work in local industry or company in the future.

19 There are too many pupils in my science class.

20 There are too many pupils in my mathematics class.

21 I always know clearly the goal of learning in math.

22 Teacher listens to our experiences and opinions and takes them into account in teaching.

23 Teacher is enthusiastic about the subject she/he is teaching.

24 The topics we study in science are relevant to me.

25 Test questions are different from what is studied in the classroom.

26 Tests measure my actual learning.

27 Teacher assigns homework and always monitors whether the homework was completed.

28 We usually listen to the teacher explaining the science content in every class.

29 We usually watch when the teacher demonstrates and explains an experiment or investigation.

30 We present and interpret data from experiments we do.

31 We memorize science facts and principles in every lesson.

32 Teacher encourages us to decide our own problem-solving procedures in math.

33 We practice skills and procedures using computers.

$34 \quad$ We use computers to process and analyze data.

35 In science lessons, we often do field trips and fieldwork as part of the school work.

36

My efforts and problems in learning math are being overlooked, and this decreases my interest in studying. 